\title{
HUMANITARIAN LOGISTICS: THE ESTABLISHMENT OF THE NIMBUSDROID PLUVIOMETRIC MONITORING SYSTEM TO RAINFALL SPATES, FLOODS AND OVERFLOWS IN THE ROCHDALE NEIGHBORHOOD
}

Camila Umbelino Carvalho Faculdade de Tecnologia de Carapicuíba, Brazil E-mail: camila.umbelino@yahoo.com.br

Érica Santos Marinho Faculdade de Tecnologia de Carapicuíba, Brazil E-mail: ericasmarinho@hotmail.com

Natália Dias dos Santos Faculdade de Tecnologia de Carapicuíba, Brazil E-mail: natalia.dias_1795@hotmail.com

Leandro Magrini do Carmo Faculdade de Tecnologia de Carapicuíba, Brazil

E-mail: leandromagrini@gmail.com

Robson Antonio Pires Faculdade de Tecnologia de Carapicuíba, Brazil E-mail: robzenfatec@gmail.com

Vinícius Ribeiro do Nascimento IJTM\&P

Faculdade de Tecnologia de Guarulhos, Brazil E-mail: vinicuis.ribeiro.nascimento@gmail.com

Dewar Taylor Carnero Chavez Faculdade de Tecnologia de Carapicuíba, Brazil E-mail: dewarchavez@gmail.com

Submission: 03/01/2017 Accept: 15/01/2017

\section{ABSTRACT}

Spates, floods and overflows are natural disasters and anthropogenic character responsible for strong impact on society. The fact that they have difficult prognosis makes the means of providing for them is uncertain, passing the condition of hostages to the populations of the areas affected by these events. Therefore, it is necessary the intervention of the Humanitarian Logistics in order to ensure emergency aid to victims. 
INDEPENDENT JOURNAL OF MANAGEMENT \& PRODUCTION (IJM\&P)

http://www.ijmp.jor.br

V. 8, n. 5, Special Edition IFLOG 2016

ISSN: 2236-269X

DOI: 10.14807/ijmp.v8i5.605

One of the factors responsible for the complexity of acting Humanitarian Logistics is the prevention of disasters through the flow of information and communications. As a possible solution, are used the rainfall monitoring systems to control water levels. Thus, the aim of this paper was to develop a rainfall monitoring system called Nimbusdroid the Rochdale neighborhood, which emphasizes the high number of incidence of these disasters. In metodological terms, bibliographical research had been used for the constitution of the theoretical basement, followed of a study of case in the quarter of the Rochdale. . As its focus, it is a qualitative and quantitative research .According to the method of approach is deductive research. Not only used in the monitoring water levels, the Nimbusdroid system forwards messages and supplies information to the applicatory site and of the same in form of alert in real time. When compared with the ALERT SMS - rainfall monitoring installed in the Osasco city - Nimbusdroid system has advantages in its functionality, a time that the ALERT SMS is unknown and requires a prior registration, different of Nimbusdroid.

Keywords: Humanitarian Logistics; Spates, floods and overflows; System of pluviometric monitoring; Rochdale; Nimbusdroid.

\section{INTRODUCTION}

One of main historical landmarks of the 18th century in Brazil was the industrialization (SANDORI, 1989). This process was not only distinguished as a transforming period of the country's economy, but also as cause of changes of the use of the ground. With the absence of an urban planning, the use of the ground grew of sped up and disordered form resulting in one of the biggest current urban problems of the great Brazilian cities (KAYRTON, 2010).

With the problems of balance between the increasing population demand and the bad planning of the division of the destined spaces the habitacional occupation, the population is influenced to search local to the housing, causing to the citizens the condition of hostages in the majority of the regions of the country disfavored and inappropriate, over all to those deriving ones of the regions poor. The increase in the unplanned urbanization and devastating occupation of the geographical space, causing problems that affect the social and economic dynamics in the national scope, and generate consequences such as: spates, floods and overflows (KAYRTON, 2010). 
INDEPENDENT JOURNAL OF MANAGEMENT \& PRODUCTION (IJM\&P)

http://www.ijmp.jor.br

v. 8, n. 5, Special Edition IFLOG 2016

ISSN: 2236-269X

DOI: 10.14807/ijmp.v8i5.605

The occurrences of spates, floods and overflows has natural and anthropogenic character, the latter being the main of typology in Brazilian events, had to the bad use of the ground on the part of the man. However, such events are only interpreted as natural disasters (earthquakes, volcanoes and hurricanes), since the predictions are complex and require preventive actions of the Government (KAYRTON, 2010).

Such panorama more reflects the lack of planning in the urbanization, becoming more comfortable the attempt of these typological disasters (KAYRTON, 2010). When relates these facts the numbers, the situation becomes even more aggravating: only in the last decade, spates, floods and overflows in Brazil had resulted in 4,5 million victims, having been 1,2 a thousand fatal (BANDEIRA; CAMPOS; BANDEIRA, 2011).

In order to minimize the damages and impacts caused by emergency catastrophes becomes necessary a specific management in disasters. This management can be divided in three phases: daily pre-disaster, disaster and postdisaster. The preparation phase of disaster is considered by the Civil Defense as the most important step of whole (or all) process, therefore it has as objective to develop projects that provide an increased capacity to emergency cases and the reduction of victims, considering a logistic support (CIVIL DEFENSE, 2000).

Social care procedures count on a wide chain of humanitarian assistance where the logistic is a critical aspect for the success of an operation of this size, given that $90 \%$ of the efforts of a disaster mitigation operation for logistic activities. The area of the logistic related to natural or emergency disasters is known as Humanitarian Logistics (TRUNICK, 2005). Composed of systems and procedures, it mobilizes financial, human resources and information as aid to the victims of natural and anthropogenic disasters or emergency character (MEIRIM, 2006).

Humanitarian Logistics also operates on prevention: with intention to brighten up the shakes of the considerable number of victims, using both rainfall and seismological monitoring systems that together with the means of communication and dissemination indicate the regions that might be affected. To receive correct information, the potential victims (those that possess greater probability to be affected) would not result in effective victims (DAY; JUNGLAS and SILVA, 2009). 
INDEPENDENT JOURNAL OF MANAGEMENT \& PRODUCTION (IJM\&P)

http://www.ijmp.jor.br

v. 8, n. 5, Special Edition IFLOG 2016

ISSN: 2236-269X

DOI: 10.14807/ijmp.v8i5.605

Within this context, an example to be cited is the Borough of Rochdale, located in the North region of the Osasco City, next to the edges of the Tietê River. The high rainfall, the lack of adequate infrastructure, the disordered urban growth and the absence of appropriate Ribeirão Vermelho stream pipes are the main reasons of frequent spates, floods and overflows in the neighborhood.

In order to increase the flow of information to the residents of the quarter of Rochdale, the Civil Defense of Osasco monitors the water levels of drainage channels with a rainfall monitoring system called ALERT SMS. After the monitoring, Civil Defense organizes the information and sends alert messages from mobile phones on the risk of overflow and flooding in the critical points of the region. However, to receive such alert messages it is necessary to perform a registration form in person in the Civil Defense of Osasco (PERES, 2014).

For lack of information on the functioning and even on the existence of ALERT SMS system, the majority of the population of the Rochdale does not usufruct the right to receive the alert messages. How much lesser it is the information given to the inhabitants, more complex is the performance of the Logistic Humanitarian, since it increases the number of victims.

Ahead of this scene, appeared the following questioning: it is possible to create a system of alternative rainfall monitoring system and to develop an application available for computers and mobile devices with alert of spates, floods and overflows in real time to the population of Rochdale? The secondary questions if guided in: the change of systems and information flows would contribute to that the population could move in a manner and with necessary time, adjusted preventively, to avoid situations of vital risks and property damages? What are the benefits presented by the new system?

This article aims to develop the rainfall monitoring system and the application "Nimbusdroid" for computers and mobile devices mobile and devices so that the population of Rochdale is alerted with the operating time required to appropriate arrangements. Furthermore, this article aims at to report on the feasibility and benefits in change for the systems and rainfall information flow.

\section{THEORETICAL EMBASAMENT}

\subsection{Humanitarian Logistics}


Humanitarian Logistics can be understood as a set formed for the planning processes, implementation and control of the efficient and efficient flow of items from the point of origin to the consumption point, evaluating the effect of vulnerable persons (THOMAS; KOPCZAK, 2007). Furthermore, Humanitarian Logistics becomes responsible for the planning, tracking, transport, supply, tracking and customs disembarrassment as responses to disasters (KOVACS; SPENS, 2007).

For Kovács and Spens (2007), Humanitarian Logistics deals with various types of natural disasters, such as terrorist earthquakes, hurricanes, tsunamis, terrorist attacks, wars, floods, overflows or even related the epidemics, droughts and famine. In this manner, it should be noted that the events could be either natural or created by the human being.

The different actors and their interactions on humanitarian supply chain, the unpredictability in the occurrence of the disaster and the lack of foresight on demand make the logistic system of complex humanitarian aid (VALBUENA; RODRÍGUEZ, 2011).

When respect to the organizations of humanitarian aid is said, has its initial landmark when foreseeing the size of the critical and importance of the management chain on the success of the operations of aid to the victims. Being about the answers to the catastrophes in the chain of humanitarian aid, one notices that its main objective is to supply information quickly, what it guarantees the success of the operations of aid to the victims (WASSENHOVE, 2006).

a) Information and Communication Technologies in Humanitarian Logistics.

One of the current challenges of the Humanitarian Logistics is to use information technology as mitigating the effects of disasters, a time that the technological investments in the area are scarce. Such panorama justifies due the limitation of financial resources and the complexity in the flow of information of the events, mainly of unexpected character (SILVA, 2011).

Humanitarian Logistics is present in disaster management. Especially in the disaster, the predecessor to stage logistics planning is extremely important for the development and implementation of preventive measures and, especially, for 
evacuation plans in case it is possible to monitor the evolution of the phenomenon (KOVÁCS; SPENS, 2007).

At the time (or moment) of occurrence of the disaster, the Information and Communication Technologies - ITCs is tools used in the mitigation of the event (MUBARAKA; KALULU; SALISU, 2013). ITCs are used with intention to foresee meteorological catastrophes, in order to minimize possible damages and losses (MOMO; SILVA; SEEVERO, 2010).

With the improvement of the capacity for rapid response, ITC assists in the communication of information, what it significantly influences in the reduction of victims, alerting the population of risk areas (MUBARAKA; KALULU; SALISU, 2013).

For Mubaraka, Kalulu and Salisu (2013), ITC increases in the increase in reliability of information in emergency situations, preventing old conflicts for discrepantes and not collected information in real time. Besides, as one of the main benefits of ITC, the information generated through the disasters can be stored in database or virtual libraries, serving as a basis for future responses, improving the management capacity of the next disasters.

\subsection{Disasters}

The disasters are generated through the relationship between natural phenomena that present some type of danger - earthquakes, hurricanes and tsunamis and certain socioeconomic and physical conditions with a high degree of vulnerability, since precarious economic situations and unstable soils the houses built precariously and in bad locations. The high risks of one or more dangerous phenomena are associated with emergency situations (ROMERO; MASKEY, 1983).

The disasters can be classified in several forms, according to their nature and their development as shown in table 1:

Table 1: Disasters typology.

\begin{tabular}{|c|c|c|}
\hline DISASTERS & NATURAL & CAUSED FOR THE MAN \\
\hline Sudden & $\begin{array}{c}\text { Avalanches, spates, volcanic } \\
\text { eruptions, hurricanes, fires, } \\
\text { floods, earthquakes and } \\
\text { tornadoes }\end{array}$ & $\begin{array}{c}\text { Chemical or nuclear accidents, } \\
\text { terrorist attack, floods, coup } \\
\text { detat and spates }\end{array}$ \\
\hline Slow development & Hunger, poverty and drought & Political crisis and refugee crisis \\
\hline
\end{tabular}

Source: Adapted of Wassenhove (2006), Kayrton (2010) and Gallego and Viñas (2011) 
An annual average of 250 million people is affected periodically by natural disasters. Of all the worldwide population exposed to natural threats, $54 \%$ of the deaths live in countries with Low Human Development Index (HDI), while the countries of high HDI shelter $15 \%$ of the population exposed to natural threats, adding the balance of $1.8 \%$ of mortal victims.

These data can be considered extremely alarming; however, do not reflect the real impacts that a disaster means in the life of people affected, in the economy, the ways of subsistence, the countries with low IDH that has few possibilities of recovery (OIT, 2016).

Beamon and Balcik (2008) affirm that in the disaster context, under the logistical function of view, it is essential to ensuring delivery of materials, human resources and information efficiently to assist emergency victims.

\section{a) Disasters in Brazil}

In Brazil, the disasters follow a regional pattern, illustrated in figure 1:

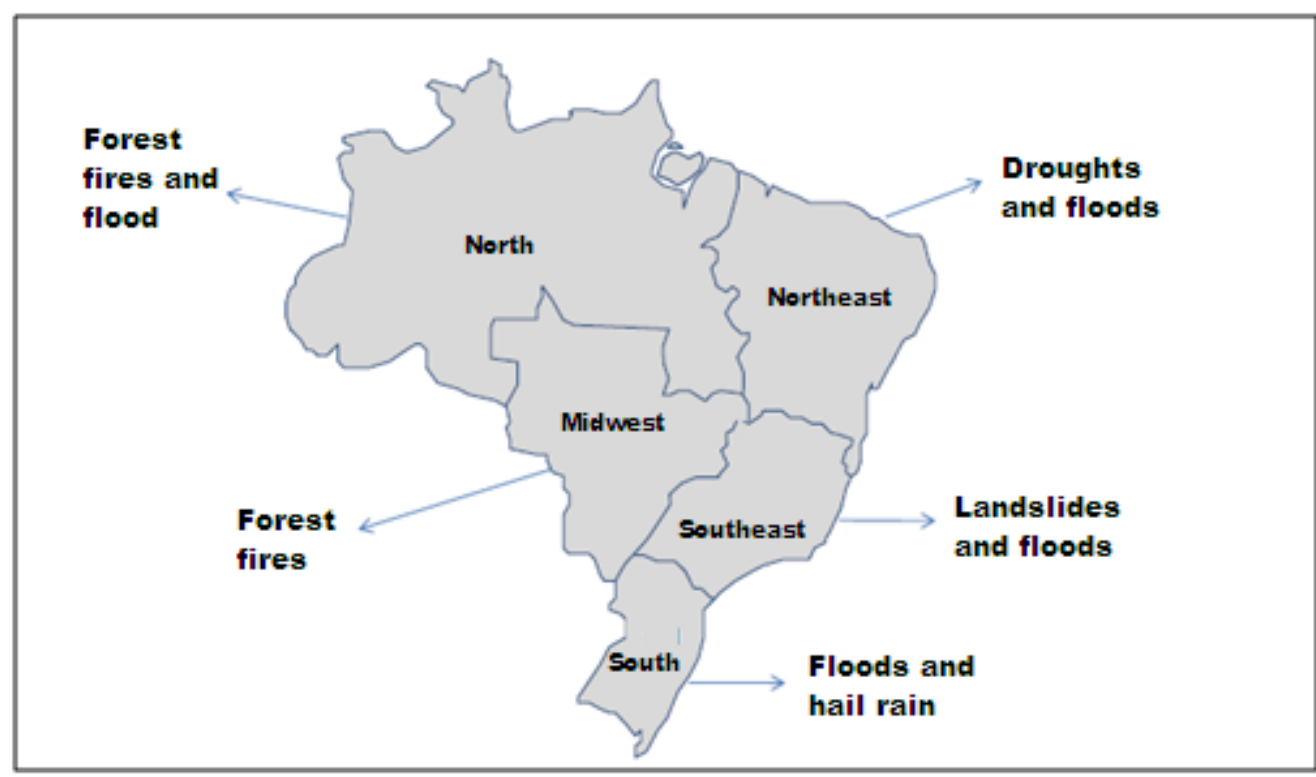

Figure 1: Types of disasters in Brazilian regions

Source: Adapted of Silva apud National Secretariat of Civil Defense (2011)

Moreira (2012) corroborates with Silva (2011) when affirming that the Brazilian disasters are recent and recurrent of the lack or excess of water: flooding, collapses of hillsides where there is human occupation or prolonged droughts.

\subsection{Spates, floods and overflows}


The spates are phenomena that occur periodically due to intense rains with the temporary increase of the volume of water in drainage channels, with the determining factor soil conditions. When drainage channels do not carry the increased volume of water overflow occurs, reaching lowland regions and marginal areas. This extra emptying of waters drainage channels is known as floods (BRAZIL, 2007; BISPO; LEVINO, 2011). The problems of drainage and seepage can also hit streets and urban centers, this phenomenon is known as overflow (BRAZIL, 2007). The figure 2 depicts the three types of phenomena:

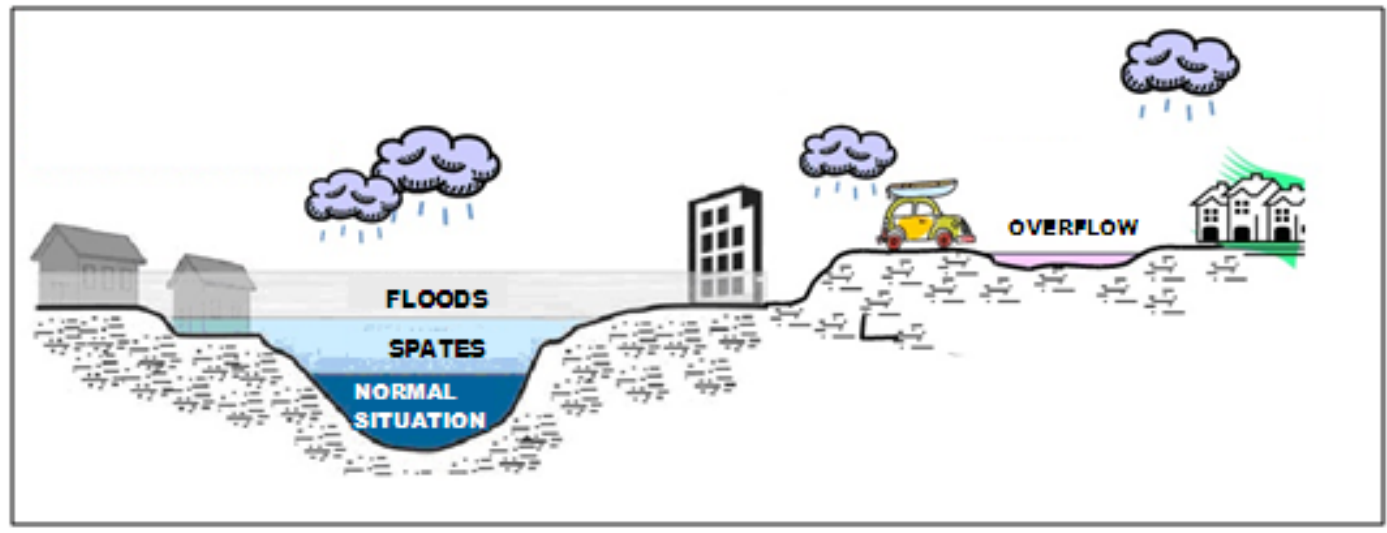

Figure 2: Difference among the events: spates, floods and overflows Source: Brazil (2007)

\section{METHODOLOGY}

For the accomplishment of this paper, was adopted the deductive method, once used the words of Galliano (1979, P. 39) "the deduction consists of taking off a truth particular of a general truth in which it is implied". According to the author, the deductive research also consists of affirming that this type of reasoning is considerably applicable when part of the known into the unknown with a low margin of error, as long as they respect the criteria of coherence and contradiction (GALLIANO, 1979).

The research classifies as qualitative and quantitative about its focus. Sampieri, Collado and Lucio (2013) affirm that the mixing methods of research promote an integration of the quantitative and qualitative methods. Such union generates a more complete view of the phenomena studied. As to its nature, the survey ranks applied, as Rodrigues (2005), the applied research produces real knowledge and with a practical application. 
As for to the technical procedures were employed two methods: a bibliographical research, using primary and secondary sources like newspaper articles, magazines, conference proceedings, dissertations and theses (LAKATOS; MARCONI, 2009). It was also a case study in employee neighborhood Rochdale. The case study method is characterized "by the deep and comprehensive study of one or a few objects, in a way that allows large and detailed knowledge" (RODRIGUES, 2005, P. 40).

\section{CASE STUDY: NEIGHBORHOOD ROCHDALE}

\subsection{Historical and geographical context}

Neighborhood Rochdale is located in the North region of the Osasco city, however before becoming neighborhood, this was just a great place that belongs to a group of businessmen, bank directors and Commissioners of the coffee that aimed to build cooperatives in this area with about of 1,250 square kilometers (PERES, 2014).

Nevertheless, in late 1940, the Tietê River underwent a rectification work in an attempt to reduce flooding, spates and also with the purpose to fill the intricacies, which are described by a sinuosity course of the Tietê River (MENECOZI, 2015).

After the rectification of this region, located in the field for cooperatives, it was termed as dead arm of the Tietê River resulting from the diversion of course, this being the problem of future spates, floods and overflows in the region (PERES, 2014).

The consolidation of the neighborhood occurred in the 1970 and 1980 owing to the completion of the River meanders, modifying then the configuration of the edges and giving origin to the housings, of irregular characteristics, the workers who acted in the cooperatives. Entrepreneurs provided batch plants and financed the construction materials in installments that were being paid over time by workers, which benefited 174 families at the time.

This process gave beginning to a wild urbanization to the edges of the river, shown in the figure 3 , these being the areas more prone to flooding because they are located in a region that should be fully open by being lowland areas (region for flood during the full ones) of the Tietê River itself, which explains the reason of 
spates and, therefore, floods and overflows in place (PERES, 2014). The figures 3 and 4 illustrate the described situation above.

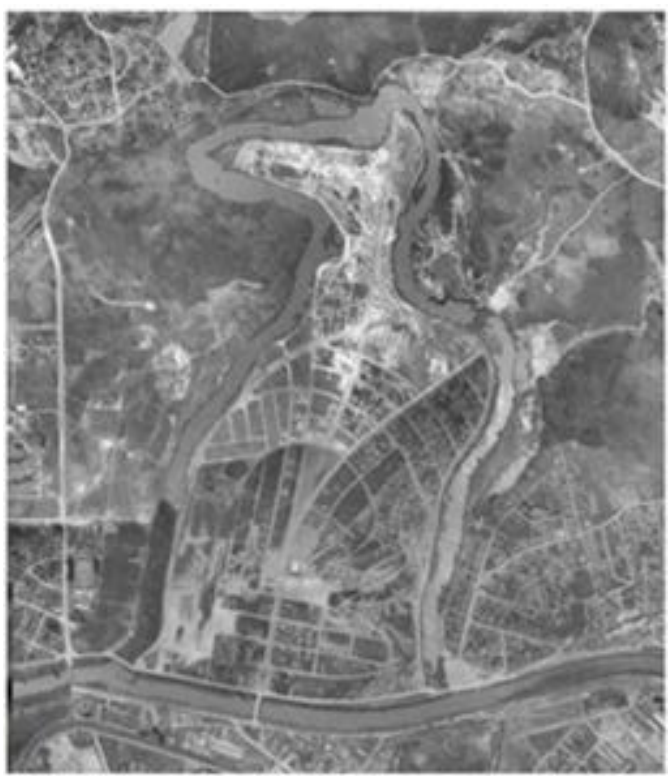

Figure 3: Aerial Photo of Rochdale from 1958

Source: Peres (2014)

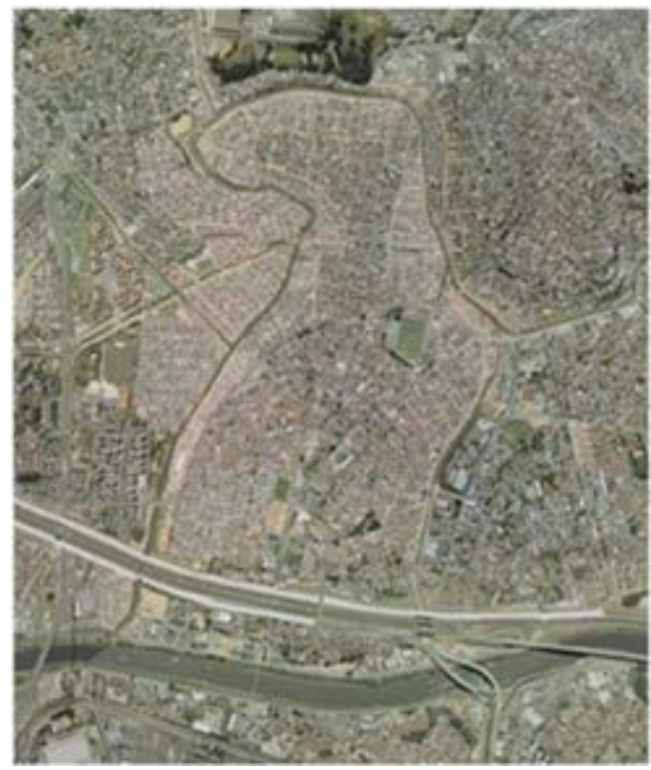

Figure 4: Aerial Photo of Rochdale from 2013

Source: Peres (2014)

Due to the huge history of spates, floods and overflows, the neighborhood Rochdale is considered a risk region the local population for years (GOMES, 2012). The residents, for lack of knowledge and information on how to proceed in cases of floods and overflows, end up climbing walls in an attempt to escape the waters. However, many physical structures are damaged in these emergency events, increasing the number of victims (DONIZETE, 2014).

In early 2015 a intense rain reached all the city of São Paulo and part of its region metropolitan: the neighborhood Rochdale was considered the most wronged, being one of the hardest hit $(\mathrm{G} 1,2015)$.

\subsection{The functioning of pluviometry Alert Sms system}

In order to predict potential disasters featured in the neighborhood, the Civil Defense has developed a rainfall monitoring system with the aim of alerting the population at risk of spates, floods and overflows. This system known as ALERT SMS sends text messages with one hour in advance to residents of areas of risk alerting the increase in rainfall in the region. For sending these messages, the Civil 
Defense uses water meters called Lighthouses, located in the gutters of the rivers (PERES, 2014)

To receive these informative messages, it is necessary that the residents are registered in the Civil Defense System. To register, the interested citizen must heading the Civil Defense of the city of Osasco and provide your personal information, including phone number, being this the main information for the registration is performed correctly. Without the record attendance at preventive programme for Civil Defense and with no other source of information, the residents of the district back to the hostage of etching disasters in the region (PERES, 2014).

\section{THE CREATION OF NIMBUSDROID MONITORING SYSTEM}

The term "Nimbus" comes from the Latin in which it means cloud. The clouds are thick and are approximately 2000 meters high, however, scrap in rain, main event responsible for spates, floods and overflows (MARTINS apud HOWARD, 2016). In this case, Nimbus is the first part of the name of the system created and proposed as a preventive tool reported in this paper. The second part of the name, the suffix of the word Android: "droid", to compose the theme. Lecheta (2013) sets the Android as a system designed for mobile devices. In the proposed system, a means of communication with the community is accomplished through an application to the Androids, justifying the Nimbusdroid name.

\subsection{The functioning of the system}

The premise of the Nimbusdroid system is to provide in skillful time the information gathered by ground-based equipment to the local population. The equipment is installed in the edge of the drainage channel or in some local considered critical/strategic, in which it is possible to monitor rainfall levels.

The equipment has a central structure responsible for the water level sensor, measuring and collecting information autonomously to feed the database 24 hours a day. The stems are aluminum structures or equivalent material to support the equipment and maintain the level sensor vertically positioned relative to a flat surface.

The CASE it is a rectangular plastic box of remote system which has sufficient capacity to accommodate all necessary components for the functioning of the equipment. Among its objectives are: to send the messages generated by the water 
DOI: 10.14807/ijmp.v8i5.605

level sensor, ensure the necessary resource to feed energy equipment, provide internet access and trigger sound and light alarms. At the top of the equipment are located the alarms responsible for alerting the local community through the shooting of an audible and visual alarm. In Figure 5 are identified in more detail the locations of the parts of the equipment:

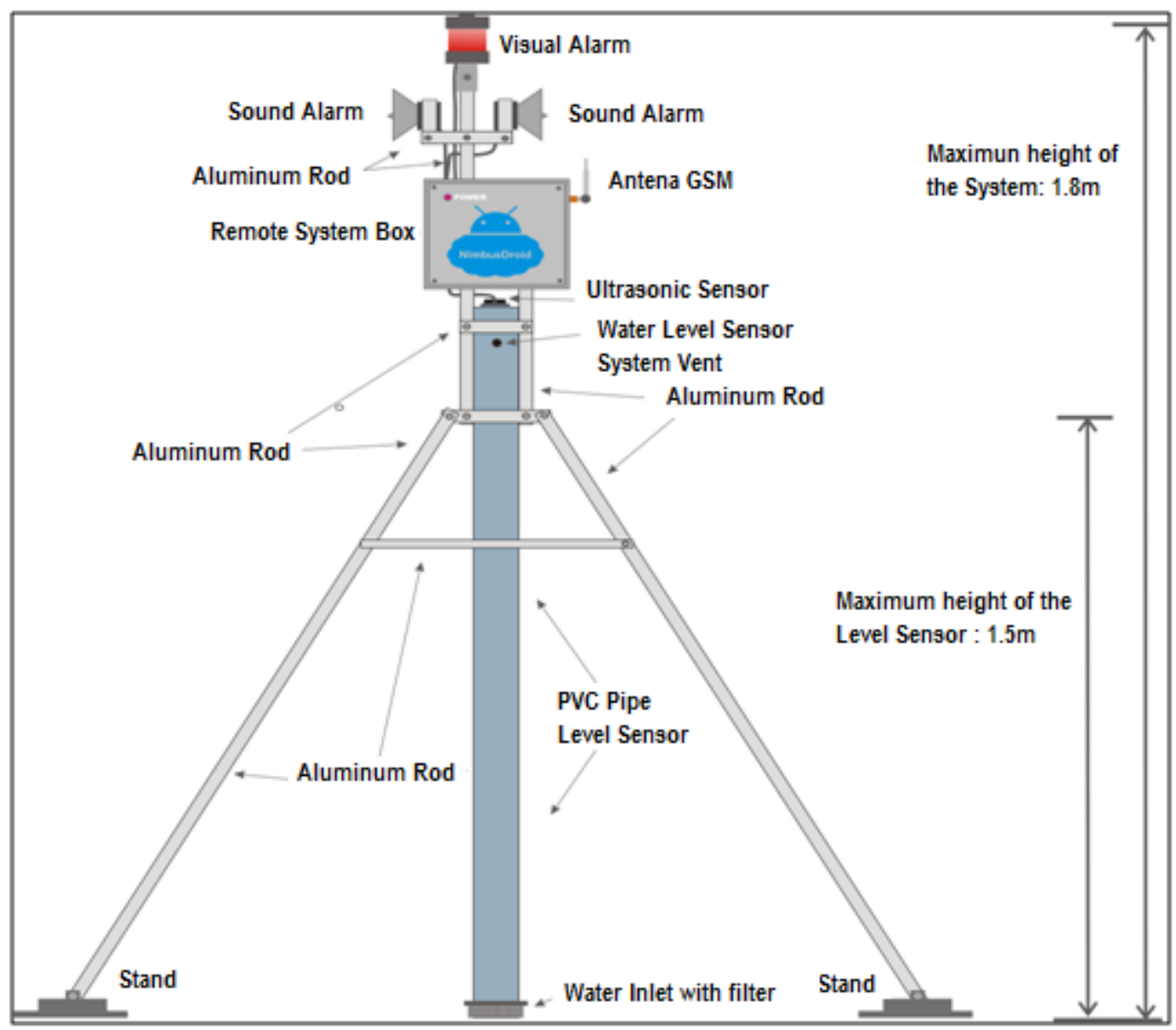

Figure 5: Side view of Nimbusdoid equipment Source: Elaborated for the authors (2016)

The system works regardless of whether it rains or not, the sensor checks the centimeters of water since there are other secondary factors to occur flood drainage channels. However, rain is the main cause of the spates and floods and overflows. The CASE will convert the centimeters into information, as shown in figure 6, where, for representative purposes, were adopted as parameters the centimeters illustrated in picture, however every drainage channel or critical site reaches different levels in centimeters corresponding to their risk, Nimbusdroid system also enables new standardization of centimeters, according to the real need of place to be deployed. 


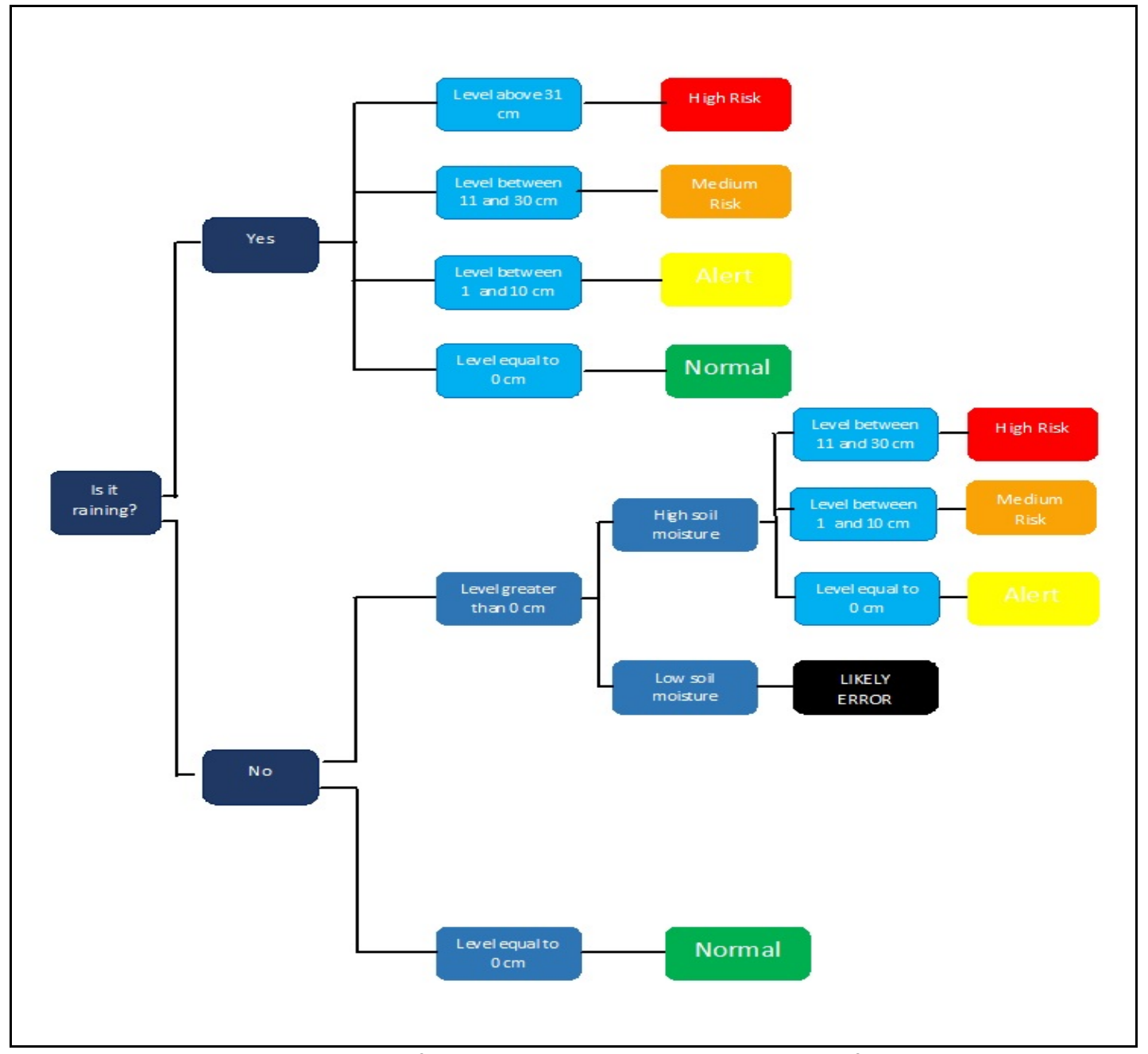

Figure 6: Vision of data conversion in system information Source: Elaborated for the authors (2016)

The converted data in information is sent to a database, so that these aid in the control and understanding of present and future emergency events.

Similar to ALERT SMS system, Nimbusdroid system provides information and dispatches them to the numbers of registered phones, however the system created provides users with two ways of interaction in addition to sending messages: the site and the Android application. The site features information on two conditions: the water level and the type of behavior of the place where it is represented by the colors green (normal), yellow (alert), Orange (medium risk situation) and Red (high risk situation). The Nimbusdroid application provides the same information. What differs is that the application when fired maintains a constant connection with the site without the need of an internet browser, however access to information on the site can be accessed via any browser type in a mobile device, shown in Figure 7. 

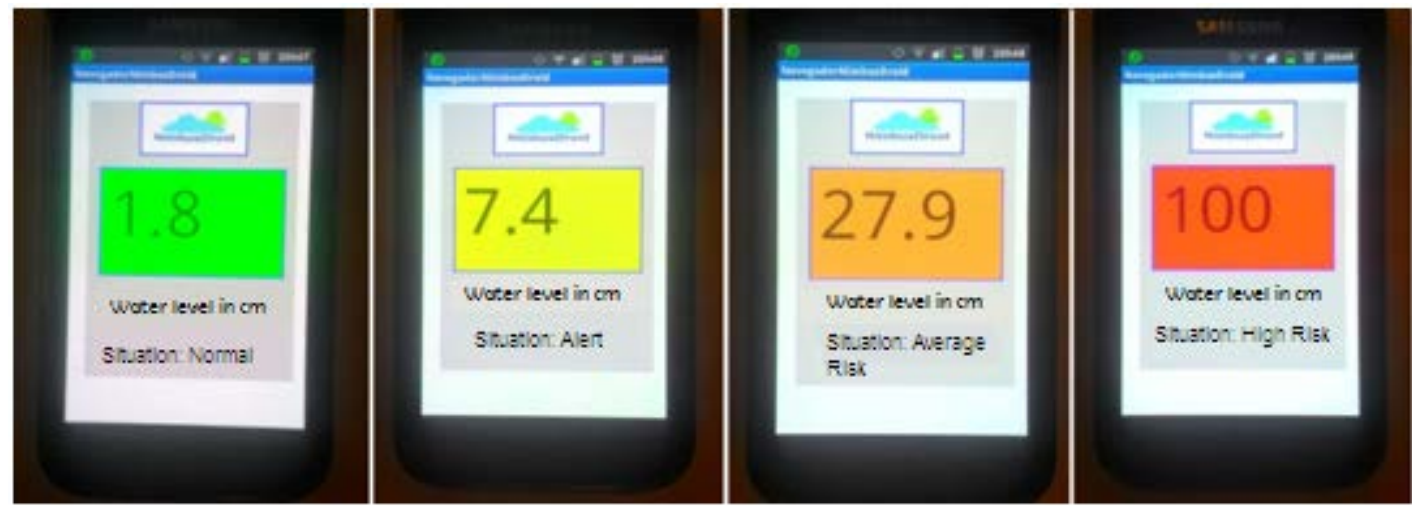

Figure 7: The functioning of Nimbusdroid application on a mobile device Source: Elaborated for the authors (2016)

The Nimbusdroid system offers six main use cases: monitor water levels; connect with the telephony network; Press audio/visual alarm; feed the database; dispatch messages and maintain direct contact with the system administrator.

\subsection{Comparative analysis between Alert SMS and Nimbusdroid systems}

The table below represents a comparative analysis on the functioning of the two rainfall systems described above.

Table 2: Comparative Analysis between the ALERT SMS and Nimbusdroid Systems

\begin{tabular}{|c|c|c|}
\hline DESCRIPTION & \multicolumn{2}{|c|}{ SYSTEMS } \\
\hline & ALERT SMS & NIMBUSDROID \\
\hline \multirow{2}{*}{ User registration } & \multirow{2}{*}{ So in person in Civil Defense. } & $\begin{array}{c}\text { Text messages: attendance in Civil } \\
\text { Defense. }\end{array}$ \\
\hline & & $\begin{array}{c}\text { Website and application: it is not } \\
\text { necessary to register. }\end{array}$ \\
\hline $\begin{array}{l}\text { Communication } \\
\text { channel to the user }\end{array}$ & Text messages & $\begin{array}{l}\text { Text messages, mobile application, } \\
\text { site system and audio/visual alert. }\end{array}$ \\
\hline \multirow{2}{*}{$\begin{array}{l}\text { Information generated } \\
\text { by the system }\end{array}$} & $\begin{array}{l}\text { Civil Defense: information and alert } \\
\text { of spates, floods and overflows in } \\
\text { text form and water levels. }\end{array}$ & \multirow{2}{*}{$\begin{array}{l}\text { Civil Defense and population: } \\
\text { information and alert of spates, } \\
\text { floods and overflows in text form, } \\
\text { water level and behavior of the } \\
\text { place following a risk criterion. }\end{array}$} \\
\hline & $\begin{array}{l}\text { Population: alert of floods and } \\
\text { overflows in text form. }\end{array}$ & \\
\hline Investment & $\begin{array}{l}\text { Has no investment in its acquisition, } \\
\text { the investment is intended for } \\
\text { maintenance and dissemination. }\end{array}$ & $\begin{array}{l}\text { Investment in construction, } \\
\text { dissemination and maintenance. }\end{array}$ \\
\hline $\begin{array}{l}\text { Occurrence of } \\
\text { problems in the } \\
\text { transmission of } \\
\text { information }\end{array}$ & $\begin{array}{c}\text { If there is a problem in the } \\
\text { transmission of messages occurs, } \\
\text { the population will not have access } \\
\text { to information. }\end{array}$ & $\begin{array}{l}\text { If there is a problem in the } \\
\text { transmission of messages occurs, } \\
\text { the audio/visual alarm will continue } \\
\text { in operation. }\end{array}$ \\
\hline $\begin{array}{l}\text { Time of dispatch of } \\
\text { expedition }\end{array}$ & $\begin{array}{l}\text { I real time information to Civil } \\
\text { Defense, however the information } \\
\text { to the population occur with one } \\
\text { hour in advance of the events. }\end{array}$ & $\begin{array}{l}\text { Information in real time to Civil } \\
\text { Defense and the population. }\end{array}$ \\
\hline
\end{tabular}

Source: Elaborated for the authors (2016)

Therefore, ALERT SMS and Nimbusdroid have their own characteristics in which can be considered to be advantages and disadvantages. However according 
to table 2, it has been possible to ascertain that the Nimbusdroid system has a more effective action in the flow of information, since it also has other means of alert as audio/visual alarms.

\section{FINAL CONCLUSIONS}

In accordance to the fact that several people are struck by spates, floods and overflows, the area of the Humanitarian Logistics has its lead role in aid of the victims of these events. In this context, this area also operates in the preventive phase so that these disasters, natural and anthropogenic characterized, not affect so devastating to the population.

For such, the rainfall monitoring systems are one of the preventive measures of Civil defence as a tool to aid to people who live and circulating in areas of risk of spates, floods and overflows. The Civil Defense of the Osasco - city this characterized by its high rates of occurrence of these disasters, having as has detached neighborhood Rochdale - possess ALERT SMS in order to control the water levels and to send text messages to residents of the region as a alert.

To gain access to messages sent by ALERT SMS, it is necessary the displacement of the resident to the city Civil Defense to perform your record. However, from the point of view of the residents and merchants of Rochdale, the majority is unaware of the existence of the system and the expert of this minority is not registered, so do not get preventive messages.

The deployment of a system that works by means of website and application without the need to record attendance and to inform in real time water levels and their respective degrees of risk are factors that fostered the creation of the Nimbusdroid system for better control and greater spread of alert the local population. Besides the Nimbusdroid system also provides audio/visual alerts coming sirens installed in your equipment.

The study achieved its objectives fully, as proposed, providing subsidies on the possible benefits in exchange between ALERT SMS and the Nimbusdroid. Thus, the implementation of Nimbusdroid would help mitigate the number of victims and the financial resources generated by the lack of information and communication of these disasters, reducing the complexity of the flow and storage of information. 
When storing the information, these serve as a basis for future events, as this point is one of the greatest challenges of the Humanitarian Logistics today.

\section{REFERENCES}

BANDEIRA, R. A. M.; CAMPOS, V. B. G.; BANDEIRA, A. P. F. (2011) Uma visão da logística de atendimento a população atingida por desastre natural. Available:http://aquarius.ime.eb.br/ webde2/prof/vania/pubs/2011/logisticaANPET.pdf Access em: 02nd June, 2016.

BEAMOM, B. M.; BALCIK, B. (2008) Facility location in humanitarian relief. Available:https://catalyst.uw.edu/workspace/file/download/e0d1e5bb77c3e74dd287fc8 d7680a71796ca91490c9ae7a8851443d3c48420193.Access:15th June, 2016.

BISPO, T. C.; LEVINO, N. A. (2011) Impactos ambientais da ocupação desordenada do solo: Um estudo da região da periferia de Maceió/AL. Available:http://www.abepro.org.br/biblioteca/enegep2011_tn_sto_143_901_18402.p df Access: 30th August, 2016.

BRASIL. Ministério da Integração Nacional. Secretaria Nacional de Defesa Civil. (2007) Política Nacional Defesa Civil. Brasília: SEDEC. Available: http://www.mi.gov.br/c/document library/get file?uuid=6aa2e891-98f6-48a6-8f47147552c57f94\&groupld=10157. Äccess: 10th June, 2016.

DAY, J. M.; JUNGLAS, I.; SILVA, L. (2009) Information Flow Impediments in Disaster Relief Supply Chains. Journal of the Association for International Systems, v. 10, n. 8, p. 637-660.

DEFESA CIVIL. Política Nacional Defesa Civil. (2000) Disponível em: http://www.integracao.gov.br/c/document_library/get_file?uuid=6aa2e891-98f6-48a68f47-147552c57f94\&groupld=10157. Access: 10th June, 2016.

DEFESA CIVIL. (2016) Enchente, Inundação ou Enchurrada? Available: http://dcsbcsp.blogspot.com.br/2011/06/enchente-inundacao-ou-alagamento. html?showComment=1461593109477\#c63. Access em 11th June, 2016.

DONIZETE, R. (2014) Chuva provoca enchentes em Osasco. Available: http://correiopaulista.com/2013/chuva-provoca-enchente-em-osasco/ Access: 11 January. 2016.

G1. (2015) Temporal coloca SP em atenção e alaga bairro de Osasco. Available:http://g1.globo.com/sao-paulo/noticia/2015/01/temporal-coloca-sp-ematencao-e-alaga-bairro-de-osasco.html. Access: 20th November, 2015

GALLIANO, A. G. (1979) O método científico: teoria e prática. São Paulo: Harbra.

GALLEGO, R. C.; VIÑAS, J. B. (2011) Logística y Tecnología en la Acción Humanitaria. In: Tecnologías para el desarrollo humano de las comunidades rurales aisladas. Espanha: Real Academia de Ingeniería, p. 427-447.

KAYRTON, R. (2010) Ocupação urbana desenfreada e o meio ambiente. Available:https://qualidadeonline.wordpress.com/2010/10/21/ocupacao-urban adesenfreada-e-o-meio-ambiente/ Access: 30 August,2016. 
KOVÁCS, G.; SPENS, K. M. (2007) Humanitarian Logistics in Disaster Rellef Operations. International Journal of Physical Distribution \& Logistics Management, v. 37, n. 2, p. 99-114.

LAKATOS, E. M.; MARCONI, M. A. (2009) Fundamentos de metodologia cientifica. 6 ed. São Paulo: Atlas.

LECHETA, R. R. (2013) Google Android: Aprenda a criar aplicações para dispositivos móveis com Android SDK.3. Ed. São Paulo: Novatec Editora, p. 821.

MARTINS, S. (2016) As nuvens possuem nomes? Available: http://meteoro pole.com.br/2011/10/as-nuvens-possuem-nomes/. Access: 18th June.

MEIRIM, H. (2006) Logística Humanitária \& Logística Empresarial. Available: http://www.administradores.com.br/artigos/carreira/logistica-humanitaria-logisticaempresarial/12685/. Access: 01st April, 2016.

MENECOZI, A. R. (2015) Meandros dos rios e a harmonia na planície. $O$ progresso. January. Available: http://www.progresso.com.br/especiais/dmais/meandros-dos-rios-e-a-harmonia-na-planicie. Access: 10th June, 2016.

MOMO, R. M.; SILVA, G. S.; SEVERO, L. D. (2010) Tecnologias da informação baseadas em serviços, aplicada em sistemas de monitoramento e alerta de eventos climáticos. In: Seminário Interinstitucional de Ensino Pesquisa e Extensão, XIII Mostra de Iniciação Cientifica.

MOREIRA, A. L. S. (2012) Cadeia logística humanitária no Brasil: coordenação eficaz nos momentos de crise. Revista de Logística da Fatec Carapicuíba, v. 2, p. 6-26.

MUBARAKA, C. M.; KALULU, R. A; SALISU, M. J. (2013) Information Tecnology and humanitarin emergency response management in WFP Uganda: A behavioral perspective. Global Journal of commerce \& management perspective. v. 2, n. 3, p.147-153.

OIT- Organização Internacional do Trabalho. (2006) A Redução do Risco de Desastres: Uma Chamada para Ação. Available: http://www.mobiliza dores.org.br/wp-content/uploads/2014/05/reduo-do-risco-de-desastres.pdf Access: 30th May, 2016.

PERES, J. S. S. S. (2014) Áreas de Risco - Degradação do tecido urbano no município de Osasco/SP. Dissertação (Graduação em Geografia) - Faculdade de Geografia, Centro Universitário Sant'Anna, São Paulo.

RODRIGUES, M. G. V. (2005) Metodologia de pesquisa: Elaboração de projetos, trabalhos de dissertações. 2.ed .Rio de janeiro: EsAO.

ROMERO, G.; MASKEY, A. (1983) Los desastres no son naturales. Perú: Centro de Estudios y Prevencion de Desastres, p. 1-7.

SAMPIERI, R. H.; COLLADO, C. F.; LUCIO, M D. P. B. (2013) Metodologia de Pesquisa. $5^{\text {a }}$ Edição Porto Alegre: Penso.

SILVA, L. C. F. (2011) Gestão da Logística Humanitária: proposta de um referencial teórico. Rio de Janeiro: Instituto COPPEAD de Administração. Originalmente apresentada como dissertação de pós-graduação, Universidade Federal do Rio de Janeiro. 
THOMAS, A. E.; KOPCZAK, L. R. (2007) Life-saving supply chains - challenges and the path forward. In: LEE, H. L.; LEE, C. Y. (Eds), Building Supply Chain Excellence in Emerging Economies, Springer, New York, 2007.

TRUNICK, P. (2005) Special report: delivering relief to tsunami victims. Logistics Today, v. 46, n. 2, p. 1-3.

VALBUENA, K. V. M.; RODRÍGUEZ, L. J. G. (2011) Relación entre recursos, eficiencia y tiempo de respuesta del sistema logístico de atención humanitaria desde un enfoque sistémico. In: Encuentro Colombiano de Dinámica de Sistemas, 9.

Anais... Bogotá: Universidad Colegio Mayor de Nuestra Señora del Rosario, p. 37 43.

WASSENHOVE, V. (2006) Blackett Memorial Lecture Humanitarian aid logistics: supply chain management in high gear. Available: in:

$<$ http://www.insead.edu/facultyresearch/centres/isic/humanitarian/documents/JORS Blackettmemoriallecture_Humanitarianaidlogistics-

Supplychainmanagementinhighgear.pdf. Access: 03rd June, 2016 